\title{
OPTIMIZING NITROGEN RATE AND PLANTING DENSITY FOR SUNFLOWER UNDER IRRIGATED CONDITIONS OF PUNJAB
}

\author{
K. Rasool, A. Wajid, Sanaullah ${ }^{* 1}$, A. Ghaffar ${ }^{1}$, M. Shoaib ${ }^{1}$ \\ M. Arshad ${ }^{1}$ and S. Abbas ${ }^{1}$ \\ Department of Agronomy, University of Agriculture, Faisalabad, Pakistan
}

\begin{abstract}
A field study was conducted at different nitrogen rates on growth, yield and achene oil content of sunflower sown at different planting densities at Faisalabad, Punjab, Pakistan. Randomized complete block design with split plot arrangement was applied, having plants densities (8.33, 6.67 and 5.56 plants $\mathrm{m}^{-2}$ ) in main plots and while various nitrogen levels $\left(90,120\right.$ and $\left.150 \mathrm{~kg} \mathrm{ha}^{-1}\right)$ in sub-plots. The plant densities and various nitrogen levels had a significant effect on leaf area index, crop growth rate, 1000-achene weight, head diameter, number of achenes head ${ }^{-}$ ${ }^{1}$,biological yield, oil quality, harvest index and achene yield of sunflower. The plants which were fertilized at $150 \mathrm{~kg} \mathrm{~N}^{-1}$ gaveabout $24 \%$ more achene yield as compared to $90 \mathrm{~kg} \mathrm{~N} \mathrm{ha}^{-1}$. More oil content was obtained in plots where nitrogen was applied at the rate of $90 \mathrm{~kg} \mathrm{ha}^{-1}$. It can be concluded that nitrogen application at the rate of $150 \mathrm{~kg} \mathrm{ha}^{-1}$ with planting density ( 8.33 plants $\mathrm{m}^{-2}$ ) produced highest achene yield.
\end{abstract}

Keywords: Sunflower, Nitrogen, Plant population, Head diameter, Achene yield, Pakistan.

\section{INTRODUCTION}

Due to ever increasing consumption of edible oil, however facing a severe shortage of edible oil in Pakistan. The local oil production is raised up to 0.612 million tons, which accounts for $23 \%$ of domestic necessity while the remaining $77 \%$ is met through imports. The sunflower has been recognized as a crop with high potentials that can successfully meet future oil requirements. Sunflower oil is a quite edible because it has soluble vitamins $\mathrm{A}, \mathrm{D}, \mathrm{E}$ and $\mathrm{K}$ and contains $60 \%$ poly unsaturated fatty acids as well as $16.25 \%$ oleic acid and $75.5 \%$ linoleic acid, having a positive effect on human health (Saleem et al., 2003). Although, this crop can be

\footnotetext{
* Corresponding author email: sanaullah.aro@gmail.com

${ }^{1}$ Agronomic Research Institute, Faisalabad, Ayub Agricultural Research Institute, Faisalabad, Pakistan
} 
suitable in the existing cropping system of Pakistan but average yield is much lower than world's average due to poor soil fertility, lack of proper production technology, high costs of inputs, and marketing problems.

A suitable plant population is of prime importance in sunflower production. Weiss (2000) reported that the achene's yield of sunflower increases to a specific level by increasing the plant population. Plant density did not affect the radiation use efficiency but differences in total dry matter production due to variation in the leaf area index (Ferreira \& Abreu, 2001). Plant population can be maintained by adjusting row to row or plant to plant spacing. Ishfaq et al. (2009) reported that sunflower sown on $60 \mathrm{~cm}$ apart rows produced significantly higher achene yield than $45 \mathrm{~cm}$. The increase in yield with narrow rows was largely related to increased higher leaf area index and maximum crop growth rate. Increasing plant population decreased stem and head diameter and enhanced plant height (Mojiri \& Arzani, 2003). Achene yield and 1000-achene weight of sunflower increased with increasing row spacing (Diepenbrock et al., 2001) whereas, Nel et al. (2000) concluded that achene yield and achene weight of sunflower decreases by increasing the plant population. Higher plant populations produce lighter seeds, thinner stems, taller plants and more yield than lesser plant populations (Beg et al., 2007). Salehi et al. (2000) reported that increasing plant population of sunflower enhanced oil and achene yield and reached maximum at plant population of 6.67 plants $\mathrm{m}^{-2}$ with $25 \mathrm{~cm}$ plant spacing.

Nitrogen plays an important role in improving the growth, yield as well as quality of all crops (Ullah et al., 2010). The yield of sunflower increased by 19 to $40 \%$ in response to nitrogen (Zubillaga et al., 2002). Moreover, a higher rate of nitrogen increases photosynthetic processes, leaf area production; leaf area duration as well as net assimilation rate and ultimately contributing towards higher grain yield (Rafiqet al., 2010). Improvement and development of leaf area, crop growth rate and radiation interception are affected by the utilization of nitrogen (Nasim et al., 2012).

The higher yield resulted where nitrogen fertilizer rate was $180 \mathrm{~kg} \mathrm{ha}^{-1}$ than other rates of nitrogen fertilizer $\left(0,60,120,240 \mathrm{~kg} \mathrm{ha}^{-1}\right)$. Scheiner et al. (2002) reported that excess nitrogen fertilizer application in sunflower causes increases environmental risk, decreases the quality of achene and oil contents and also reduces the achene yield due to lodging of plants.

Therefore, the present study was conducted to evaluate the effect of different nitrogen rates on growth, grain yield and achene oil contents of sunflower planted at various planting densities under agro-ecological conditions of Faisalabad, Punjab, Pakistan.

\section{MATERIALS AND METHODS}

The experiment was conducted at Agronomic Research Area, University of Agriculture, Faisalabad $\left(31^{\circ} .40^{\prime \prime} \mathrm{N}, 73^{\circ} .11^{\prime \prime} \mathrm{E}\right)$. The soil is sandy clay loam according to USDA classification (Anon., 1998).The analysis of soil was carried out before sowing the crop. Composite soil samples were collected from the experimental area at depth of 0-15 and 15-30 $\mathrm{cm}$ (Table 1). 
The experiment was conducted during the spring season of 2012. The experiment was laid out in split plot arrangement having three replications. There were three planting populations $\left(8.33,6.67\right.$ and 5.56 plants $\mathrm{m}^{-2}$ ) in main plot and three nitrogen levels $\left(90,120\right.$ and $\left.150 \mathrm{~kg} \mathrm{ha}^{-1}\right)$ in sub plot. To achieve plant population of $8.33,6.67$ and 5.56 plants $\mathrm{m}^{-2}$; plant to plant distance was maintained at 20,25 and $30 \mathrm{~cm}$, respectively along with row spacing of $60 \mathrm{~cm}$. After field preparation flat sowing was done with hand drill. The crop was sown on 1 March, 2012. After germination and seedling establishment, plants were thinned to one plant per hill. Crop was irrigated with canal water using surface irrigation method. Phosphorus and potash were applied @ 100 and $60 \mathrm{~kg} \mathrm{ha}^{-1}$ respectively. Diamonium phosphate (DAP) and sulphate of potash were the source of phosphorus and potash respectively. Whole amount of phosphorus and potash was applied at sowing. First irrigation was applied just after planting of seeds and subsequent irrigations were applied on fortnightly basis up to flowering with amount of three acre inch. To control weeds, the plots were hoed twice. Following earthing up manuallyto protect it from lodging. Nitrogen fertilizer was applied in 3 splits in the form of urea. $1 / 3^{\text {rd }}$ dose was applied at the time of seed bed preparation, $1 / 3^{\text {rd }}$ at 7 days after sowing and remaining $1 / 3^{\text {rd }}$ at third irrigation. All other agronomic practices uniform for all the treatments. The crop was harvested on 15th June, 2012.

A sample of five plants was selected in each plot fortnightly for measuring growth parameters such as leaf area index, total dry matter production and crop growth rate. Ten plants were selected for the determination of different yield attributes like plant height, head diameter, number of achenes head ${ }^{-1}, 1000$-achene weight and achene yield at final harvest. The harvest index was calculated as the ratio of grain yield by biological yield. The oil contents were determined by soxhlet fat extraction method and oil yield was calculated by multiplying total achene yield with oil content.

The experimental data was statistically analyzed using the statistical computer software MSTAT-C.and least significance difference (LSD) test at $\mathrm{P} \leq 0.05$ was used to compare the differences among treatments means.

\section{RESULTS AND DISCUSSION}

\section{Leaf area index}

The result showed that leaf area index (LAI) progressively increased and achieved its maximum value at 60 days after sowing (DAS) when anthesis started (Figure 1.). Thereafter LAI decreased in all treatments and reached its minimum at 80 DAS. The LAI increased with increase in nitrogen levels from 90 to $150 \mathrm{~kg} \mathrm{~N} \mathrm{ha}^{-1}$. The treatment where nitrogen was applied @ $150 \mathrm{~kg} \mathrm{ha}^{-1}$ achieved maximum LAI (4.5) which was at par with $120 \mathrm{~kg} \mathrm{~N} \mathrm{ha}^{-1}$ while minimum LAI (3.6) was observed at $90 \mathrm{~kg} \mathrm{ha}^{-1}$. Plants which were fertilized at $150 \mathrm{~kg} \mathrm{~N}^{-1}$ attained $24.6 \%$ more LAI than fertilized with $90 \mathrm{~kg} \mathrm{~N} \mathrm{ha}^{-1}$. More LAI ensure the higher photosynthetic rate, 
which further facilitate the higher dry matter accumulation. Similarly, more LAI could be due to significant developments in leaf expansion, for example, length and breadths of the leaves that might be dependent upon high nitrogen rates. The positive effect of nitrogen on LAI of sunflower hybrids has also been reported by Bange et al. (2000).

LAI increased linearly with increase in plant population from 5.56 to 8.33 plants $\mathrm{m}^{-2}$. Maximum LAI (4.7) was recorded with planting density 8.33 plants $\mathrm{m}^{-2}$ and it was statistically similar at planting population of 6.67 plants $\mathrm{m}^{-2}$. Plant population 5.56 plants $\mathrm{m}^{-2}$ produced minimum LAI (3.3). The relationship between LAI and achene yield was linear and positive, with value of $\left(\mathrm{R}^{2}=0.65\right)$ as shown in figure 3.

\section{Total dry matter $\left(\mathrm{kg} \mathrm{ha}^{-1}\right)$}

Figure 2 indicated that the effect of nitrogen fertilizer was positive and linear in the production of total dry matter (TDM). Maximum TDM (11286 kg ha $\mathrm{kg}^{-1}$ ) was observed at $150 \mathrm{~kg} \mathrm{~N} \mathrm{ha}^{-1}$ followed by $120 \mathrm{~kg} \mathrm{~N} \mathrm{ha}^{-1}$. The nitrogen application@ 90 $\mathrm{kg} \mathrm{N} \mathrm{ha}^{-1}$ produced minimum TDM (10105 $\left.\mathrm{kg} \mathrm{ha}^{-1}\right)$. Plants which were fertilized at $150 \mathrm{~kg} \mathrm{~N} \mathrm{ha}^{-1}$ attained $11.7 \%$ more TDM than $90 \mathrm{~kg} \mathrm{~N} \mathrm{ha}^{-1}$. The enhancement in TDM with increasing rate of nitrogen fertilizer could be due to better crop growth rate, which gave maximum photosynthates. The maximum TDM $\left(11776 \mathrm{~kg} \mathrm{ha}^{-1}\right)$ was observed from 8.33 plants per $\mathrm{m}^{2}$ followed by 6.67 plants per $\mathrm{m}^{2}$. The minimum TDM (9730 kg ha ${ }^{-1}$ ) was recorded from plots where plant density was 5.56 plants per $\mathrm{m}^{2}$. Higher TDM from 8.33 plants $\mathrm{m}^{-2}$ was due to additional dry matter accumulation and more achene yield. Thses results were in accordance with Ali et al. (2014) who reported that increasing plant density along with nitrogen increased TDM; however the interaction between nitrogen and plant densities was non-significant.

The possible reason for more TDM might be that 8.33 plants $\mathrm{m}^{-2}$ would be ideal for the plants to utilize the nutrients, light and moisture and had contributed towards the promotion of total dry matter accumulation with a significant difference. The relationship between TDM and achene yield was positive and linear with values of $\left(\mathrm{R}^{2}=0.98\right)$ as shown in figure 3 .

\section{Crop growth rate $\left(\mathrm{g} \mathrm{m}^{-2} \mathrm{~d}^{-1}\right)$}

Crop growth rate (CGR) expresses the rate of dry matter accumulation per unit area per day. Mean crop growth rate was highly significant $(\mathrm{P} \leq 0.01)$ at different nitrogen rates $90 \mathrm{~kg} \mathrm{~N}^{-1}, 120 \mathrm{~kg} \mathrm{~N}^{-1}$ and $150 \mathrm{~kg} \mathrm{~N}^{-1}$ with values of $12.0,12.5$ and $14.5 \mathrm{~g} \mathrm{~m}^{-2} \mathrm{~d}^{-1}$, respectively as shown in figure 4 . The results showed that CGR increased with each successive day. Nitrogen at the rate of $150 \mathrm{~kg} \mathrm{~N} \mathrm{ha}^{-1}$ gave maximum CGR (13.4 $\left.\mathrm{g} \mathrm{m}^{-2} \mathrm{~d}^{-1}\right)$ may be attributed to more vegetative growth due to nitrogen application. Nasim et al. (2012) concluded that the nitrogen application had durable consequence on the improvement and increase of leaf area in terms of radiation interception. 
Plant population 8.33 plants $\mathrm{m}^{-2}, 6.67$ plants $\mathrm{m}^{-2}$ and 5.56 plants $\mathrm{m}^{-2}$ were highly significantly different with mean CGR values of $15.1,13.3$ and $10.6\left(\mathrm{~g} \mathrm{~m}^{-2} \mathrm{~d}^{-1}\right)$ respectively. The 8.33 plants $\mathrm{m}^{-2}$ resulted $4 \%$ more crop growth rate as compared to 5.56 plants $\mathrm{m}^{-2}$ because 8.33 plants $\mathrm{m}^{-2}$ has more number of plants per unit area. The interaction effects of different nitrogen rates and plant population were found insignificant.

\section{Plant height (cm)}

The application of nitrogen @ $150 \mathrm{~kg} \mathrm{ha}^{-1}$ produced maximum plant height $(187.9 \mathrm{~cm})$ whereas minimum plant height $(180.7 \mathrm{~cm})$ was recorded in at nitrogen level of $90 \mathrm{~kg} \mathrm{ha}^{-1}$ (Table 2). Similar results were observed with increasing the rate of nitrogen fertilizer by Ishfaq et al. (2009). The maximum plant height $(187.1 \mathrm{~cm})$ was recorded with plant population was 8.33 plants $\mathrm{m}^{-2}$ while minimum plant height $(180.8 \mathrm{~cm})$ from5.56 plants $\mathrm{m}^{-2}$. The reason of more plant height at narrow plant spacing might be due to better utilization of nutrients, light, moisture and more competition among plants as compared to more spaced plants. These results are conformity to Ali et al. (2011) who reported that with increasing plant density, the plant height increased mainly due to more supply of nutrient, light, moisture and air as compared to narrow spacing. The interaction between different levels of nitrogen and planting densities was non-significant.

\section{Head diameter $(\mathrm{cm})$}

Head size contributes substantially to achene yield because it influences both achene size and number of achenes per head of sunflower.

Head diameter was increased with increasing nitrogen levels from 90 to $150 \mathrm{~kg}$ $\mathrm{ha}^{-1}$. The maximum head diameter $(18.6 \mathrm{~cm})$ was recorded with $150 \mathrm{~kg} \mathrm{~N}$ ha ${ }^{-1}$ but statistically at par with $120 \mathrm{~kg} \mathrm{~N} \mathrm{ha}^{-1}$ while minimum head diameter $(16.0 \mathrm{~cm})$ from $90 \mathrm{Kg} \mathrm{N} \mathrm{ha}^{-1}$. These results were similar to the findings of Iqbal et al. (2008). They recorded maximum head diameter from treatment where $\mathrm{N}$ was applied @ $120 \mathrm{~kg} \mathrm{ha}^{-}$ 1 .

Head diameter was decreased with increase in plant density. Maximum head diameter $(19.1 \mathrm{~cm})$ was obtained from 5.56 plants $\mathrm{m}^{-2}$ compare to 8.33 plants $\mathrm{m}^{-2}$ which gave minimum head diameter $(16.3 \mathrm{~cm})$. The possible reason for better plant growth is due to proper utilization of nutrients, light, moisture and less plant competition with planting densities of 5.56 plants $\mathrm{m}^{-2}$. These results are in close agreement with the findings of Al-Thabet (2006) who reported that head diameter of sunflower crop was significantly increased with increase in space between plants. The interaction between different nitrogen levels and planting densities was nonsignificant.

\section{Number of achenes per head}

Results presented in table 2 exhibited that the number of achenes per head

increased with increase from 90 to $150 \mathrm{~kg} \mathrm{~N} \mathrm{ha}^{-1}$. Nitrogen application@150 kg ha 
produced higher number of achenes (1106) per head which was statistically similar with $120 \mathrm{~kg} \mathrm{~N} \mathrm{ha}^{-1}$. While $90 \mathrm{~kg} \mathrm{ha}^{-1}$ produced lowest achenes number per head (992.3). Nitrogen rate at $150 \mathrm{~kg} \mathrm{ha}^{-1}$ attained $11.5 \%$ additional number of achenes per head as compared to that in $90 \mathrm{~kg} \mathrm{~N} \mathrm{ha}^{-1}$.

Number of achenes per head increased with decrease in plant densities from 8.33 to5.56 plants $\mathrm{m}^{-2}$. The plan population 5.56 plants $\mathrm{m}^{-2}$ produced highest number of achenes per head (1167) followed by 6.67 plants $\mathrm{m}^{-2}$. The reason was that head diameter was more in 5.56 plants $\mathrm{m}^{-2}$ so it produced more number of achenes per head. While minimum numbers of achenes (954.0) per head from 8.33 plants $\mathrm{m}^{-2}$. Similar results were reported by Ali et al. (2011) they reported that with decreasing plant population the number of achenes per head of sunflower was increased. The interaction between different levels of nitrogen and planting densities was nonsignificant.

\section{0-achene weight $(\mathrm{g})$}

The data in table 2 revealed that maximum 1000 -achene weight $(42.84 \mathrm{~g})$ was recorded with $150 \mathrm{~kg} \mathrm{~N} \mathrm{ha}^{-1}$ which was at par with $120 \mathrm{~kg} \mathrm{~N} \mathrm{ha}^{-1}$ while Minimum 1000 -achene weight $(38.9 \mathrm{~g})$ at $90 \mathrm{~kg} \mathrm{~N} \mathrm{ha}^{-1}$. The plants which were fertilized at 150 $\mathrm{kg} \mathrm{N} \mathrm{Na}^{-1}$ attained almost $10 \%$ more 1000 -achene weight than $90 \mathrm{~kg} \mathrm{~N}$ ha ${ }^{-1}$. The increase in growth characters and yield components with the increase in nitrogen levels might be due to the role of nitrogen in stimulating vegetative growth. These findings are in corroborates with the results of Haq et al. (2006). They noted that nitrogen application caused increase in achene weight of sunflower hybrids. The maximum value of 1000 -achenes weight $(43.2 \mathrm{~g}$ ) was recorded with plant population of 5.56 plants $\mathrm{m}^{-2}$ statistically at par with 6.67 plants $\mathrm{m}^{-2}$ while minimum weight (39.7 g) was observed at 8.33 plants $\mathrm{m}^{-2}$. The reason for higher 1000 -achene weight could be due to less competition for light, moisture and nutrients under planting densities of 5.56 plants $\mathrm{m}^{-2}$. These results are in line with the recommendations of Al-Thabet (2006). The interaction between nitrogen fertilizer and plant spacing was nonsignificant.

\section{Achene yield $\left(\mathrm{kg} \mathrm{ha}^{-1}\right)$}

The final achenes yield per hectare is formulated by the accumulated effects of individual yield components. The maximum achene yield $\left(2908 \mathrm{~kg} \mathrm{ha}^{-1}\right)$ of sunflower was recorded at $150 \mathrm{~kg} \mathrm{~N}^{-1}$ whereas minimum achene yield $\left(2343 \mathrm{~kg} \mathrm{ha}^{-1}\right)$ at $\mathrm{N}$ $90 \mathrm{~kg} \mathrm{ha}^{-1}$ as shown in table 3. The plants which were fertilized at $150 \mathrm{~kg} \mathrm{~N} \mathrm{ha}^{-1}$ attained almost $24.1 \%$ more achene yield as compared to plants fertilized at $90 \mathrm{~kg} \mathrm{~N}$ $\mathrm{ha}^{-1}$.These results are in line with Zubillaga et al. (2002). Maximum value of achene yield $\left(2889 \mathrm{~kg} \mathrm{ha}^{-1}\right)$ was observed in plots where plant density was 8.33 plants $\mathrm{m}^{-2}$ and minimum value of achene yield $\left(2526 \mathrm{~kg} \mathrm{ha}^{-1}\right)$ of 5.56 plants $\mathrm{m}^{-2}$. The reason for more achene yield of sunflower might be due to more number of plants per hectare. Similar results were presented by Kazemeini et al. (2009). Interaction between varying nitrogen levels and plant spacing was non-significant. 


\section{Achene oil content (\%)}

Table 3 showed that plant densities had non-significant on oil contents. Oil percentage decreased with increase in nitrogen levels from 90 to $150 \mathrm{~kg} \mathrm{ha}^{-1}$. Maximum oil percentage (40.0\%) was obtained in plots which were fertilized at 90 $\mathrm{kg} \mathrm{N} \mathrm{ha}{ }^{-1}$; whereas, minimum oil percentage $(38.3 \%)$ was observed in plots where nitrogen was applied at $150 \mathrm{~kg} \mathrm{~N} \mathrm{ha}{ }^{-1}$. The nitrogen application at $90 \mathrm{~kg} \mathrm{ha}^{-1}$ produced almost $4.3 \%$ more oil contents than $150 \mathrm{~kg} \mathrm{~N} \mathrm{ha}^{-1}$. The interaction of nitrogen fertilizer level and plant densities was non-significant.

\section{Harvest index (\%)}

Plant population did not significantly effect on harvest index. Nitrogen level at $120 \mathrm{~kg} \mathrm{ha}^{-1}$ gave maximum harvest index $(25.9 \%)$ but statistically at par with $150 \mathrm{~kg}$ $\mathrm{N} \mathrm{ha}^{-1}$. Minimum harvest index $(23.3 \%)$ was observed at nitrogen rate of $90 \mathrm{~kg} \mathrm{ha}^{-1}$. Increases in $\mathrm{HI}$ with application of nitrogen at $90 \mathrm{~kg} \mathrm{ha}^{-1}$ might be due to better crop growth rate, which gave better LAI and ultimately produced optimum biological yield. Previously Jin et al. (2010) reported similar type of approaches. Harvest index increased when plant density decreased from 8.33 to 5.56 plants $\mathrm{m}^{-2}$. The lower plant population of 5.56 plants $\mathrm{m}^{-2}$ gave higher harvest index (25.9\%) as compared to other planting densities, while minimum harvest index of $24.5 \%$ was observed with 8.33 plants $\mathrm{m}^{-2}$. However, there was no difference in nitrogen fertilizer and planting densities regarding harvest index.

\section{CONCLUSION}

Nitrogen application at the rate of $150 \mathrm{~kg} \mathrm{ha}^{-1}$ and planning densities of 8.33 plants $\mathrm{m}^{-2}$ gave higher achene yield as against with nitrogen rates and planting densities. More oil contents were obtained in plots which were fertilized at $90 \mathrm{~kg} \mathrm{~N}$ $\mathrm{ha}^{-1}$. However, it recommended that sunflower should be fertilized at $120 \mathrm{~kg} \mathrm{~N} \mathrm{ha}^{-1}$ along with planting density of 8.33 plants $\mathrm{m}^{-2}$ to achieve maximum benefits.

\section{REFERENCES}

Ali, A., Afzal, M. Rasool, I.J, Hussain, S. and Ahmad, M. 2011. Sunflower (Helianthus annuus L.) hybrids performance at different plant spacing under agro-ecological conditions of Sargodha, Pakistan. International Conference on Food Engineering and Biotechnology, 9: 317-322

Al-Thabet, S.S. 2006. Effect of plant spacing and nitrogen levels on growth and yield of sunflower (Helianthus annuus L.). Journal of King Saud University Agricultural Sciences, 19: 1-11

Beg. A., Pourdad, S.S. and Alipour, S. 2007. Row and plant spacing effects on agronomic performance of sunflower in warm and semi-cold areas of Iran. Helia, 30: 99-104

Diepenbrock, W., Long, M. and Feil, B. 2001. Yield and quality of sunflower as affected by row orientation, row spacing and plant density. Australian Journal of Agricultural Research, 52: 29-36 
Ferreira, A.M. and F.G. Abreu. 2001. Description of development, light interception and growth of sunflower at two sowing dates and two densities. Mathematics and Computer in Simulation, 56: 369-384

Haq, A., Rashid, M.A. Butt, M.A. Akhter, M. Aslam, M. and Saeed. A. 2006. Evaluation of sunflower (Helianthus annuus L.) hybrids for yield and yield components in central Punjab. Journal of Agricultural Research, 44: 277-285

Iqbal, J., Hussain, B. Saleem, M.F. Munir, M.A. and Aslam, M. 2008. Bio-economics of autumn planted sunflower (Helianthus annuus L.) hybrids under different NPK applications, Pakistan Journal of Agricultural Sciences, 45: 19-24

Ishfaq, M., Ali, A. Khaliq, A. and Yaseen M. 2009. Allometry, agronomic traits and yield of autumn planted sunflower hybrids under varying row spacing. Pakistan Journal of Agricultural Sciences, 46: 248-257

Jin, J., Liu, X. Wanga, G. Mi, L. Shen, Z. Chen, X. and Herbert, S.J. 2010. Agronomic and physiological contributions to the yield improvement of soybean cultivars released from 1950 to 2006 in Northeast China, Field Crops Research, 115: 116-123.

Kazemeini, A.S. Edalat, M. and Shekoofa, A. 2009. Interaction effects of deficit irrigation and row spacing on sunflower growth, seed yield and oil yield. African Journal of Agricultural Research, 4: 1165-1170

Mojiri, A. and Arzani, A. 2003. Effects of Nitrogen Rate and Plant Density on Yield and Yield Components of Sunflower. Journal of Science and Technology of Agriculture and Natural Resources, 7: 115-125

Nasim, W., Ahmad, A. Bano, A. Olatinwo, R. Usman, M. Khaliq. T. Wajid, A. Hammad, H.M. Mubeen, M. and Hussain, M. 2012. Effect of nitrogen on yield and quality of sunflower (Helianthus annuus L.) hybrids under sub humid conditions of Pakistan. American Journal of plant Sciences, 3: 243-251

Nel, A.A., Loubser, H.L. and Hammes, P.S. 2000. The effect of plant population on the quality of sunflower seed for processing. South African Journal of Plant and Soil, 17: 6-9

Rafiq, M.A., Ali, A. Malik, M.A. and Hussain, M. 2010. Effect of fertilizer levels and plant densities on yield and protein contents of autumn planted maize, Pakistan. Journal of Agricultural Sciences, 47: 201-208

Saleem, R., Umar, F.M. and Ahmed, R. 2003. Bioeconomic assessment of different sunflower based intercropping systems at different geometric configurations, Pakistan Journal of Biological Sciences, 6: 1187-1190

Salehi, F. and Bahrani, M.J. 2000. Sunflower summer planting yield as affected by plant population and nitrogen application rates. Iran Agricultural Research, 1: 63-72

Scheiner, J.D., Gutie'rrez-Boem, F.H. and Lavado, R.S. 2002. Sunflower nitrogen requirement and $15 \mathrm{~N}$ fertilizer recovery in Western Pampas, Argentina. European Journal of Agronomy, 17: 73-79 
Ullah, M.A., Anwar, M. and Rana, A.S. 2010. Effect of nitrogen fertilization and harvesting intervals on the yield and forage quality of elephant grass (Pennisetum purpureum) under mesic climate of Pothowar plateau. Pakistan Journal of Agricultural Sciences, 47: $231-234$

Weiss, E.A. 2000. Oil seed crops Blackwell Sci. Led. London. Pp 364

Zubillaga M.M., Aristi, J.P. and Lavado, R.S. 2002. Effect of phosphorus and nitrogen fertilization on sunflower (Helianthus anпииs L.) nitrogen uptake and yield. Journal of Agronomy and Crop Science, 188: 267-274

Table 1. Physio-chemical analyses of the soil samples from Experimental Site

\begin{tabular}{ll}
\hline Determination & Values \\
\hline A. Physical Properties & \\
Sand (\%) & 62.25 \\
Silt (\%) & 16.25 \\
Clay (\%) & 21.50 \\
B. Chemical Properties & \\
pH & 7.56 \\
Organic Matter (\%) & 0.87 \\
Total Nitrogen (\%) & 0.062 \\
Available Phosphorus (ppm) & 8.90 \\
Available Potassium (ppm) & 193 \\
\hline
\end{tabular}


Table 2. Effect of different plant population and nitrogen levels on yield attributes of sunflower

\begin{tabular}{lllll}
\hline Planting population & $\begin{array}{l}\text { Plant height } \\
(\mathbf{c m})\end{array}$ & $\begin{array}{l}\text { Head } \\
\text { diameter }(\mathbf{c m})\end{array}$ & $\begin{array}{l}\text { Number of } \\
\text { achenes/head }\end{array}$ & $\begin{array}{l}\text { 1000-achene } \\
\text { weight }(\mathbf{g})\end{array}$ \\
$\left(83,333{\left.\text { plants } \mathrm{ha}^{-1}\right)}^{187.0 \mathrm{a}}\right.$ & $16.3 \mathrm{c}$ & $954 \mathrm{c}$ & $39.7 \mathrm{~b}$ \\
$\left(66,666\right.$ plants ha $\left.^{-1}\right)$ & $184.9 \mathrm{~b}$ & $17.4 \mathrm{~b}$ & $1067 \mathrm{~b}$ & $41.5 \mathrm{ab}$ \\
$\left(55,555\right.$ plants ha $\left.^{-1}\right)$ & $180.8 \mathrm{c}$ & $19.1 \mathrm{a}$ & $1167 \mathrm{a}$ & $43.2 \mathrm{a}$ \\
LSD $(5 \%)$ & 1.77 & 0.53 & 74.7 & 1.9 \\
Nitrogen levels $\left(\mathbf{k g ~ h a}^{-1}\right)$ & & & & \\
90 & $180.7 \mathrm{c}$ & $16.0 \mathrm{~b}$ & $992 \mathrm{~b}$ & $38.9 \mathrm{~b}$ \\
120 & $184.2 \mathrm{~b}$ & $18.3 \mathrm{a}$ & $1090 \mathrm{a}$ & $42.6 \mathrm{a}$ \\
150 & $187.9 \mathrm{a}$ & $18.6 \mathrm{a}$ & $1106 \mathrm{a}$ & $42.8 \mathrm{a}$ \\
LSD $(5 \%)$ & 0.98 & 1.2 & 47.7 & 2.4 \\
\hline
\end{tabular}

Table 3.Effect of different plant population and nitrogen levels on yield, oil content $\&$ HI of sunflower

\begin{tabular}{llll}
\hline Planting population & $\begin{array}{l}\text { Achene yield }(\mathbf{k g} \\
\left.\mathbf{h a}^{-1}\right)\end{array}$ & $\begin{array}{l}\text { Achene oil } \\
\text { content }(\%)\end{array}$ & Harvest index (\%) \\
$\left(83,333\right.$ plants ha $\left.^{-1}\right)$ & $2889 \mathrm{a}$ & 38.9 & 24.5 \\
$\left(66,666\right.$ plants $\left.^{-1}\right)$ & $2665 \mathrm{~b}$ & 39.0 & 24.5 \\
$\left(55,555\right.$ plants ha $\left.^{-1}\right)$ & $2526 \mathrm{~b}$ & 38.9 & 26.0 \\
LSD $(5 \%)$ & 191.5 & $\mathrm{NS}$ & $\mathrm{NS}$ \\
Nitrogen levels $\left(\mathbf{k g ~ h a}^{-1}\right)$ & & & \\
90 & $3243 \mathrm{~b}$ & $40.0 \mathrm{a}$ & $23.3 \mathrm{~b}$ \\
120 & $2829 \mathrm{a}$ & $38.6 \mathrm{~b}$ & $25.9 \mathrm{a}$ \\
150 & $2908 \mathrm{a}$ & $38.3 \mathrm{~b}$ & $25.8 \mathrm{a}$ \\
LSD $(5 \%)$ & 134.6 & 0.89 & 1.37 \\
\hline
\end{tabular}




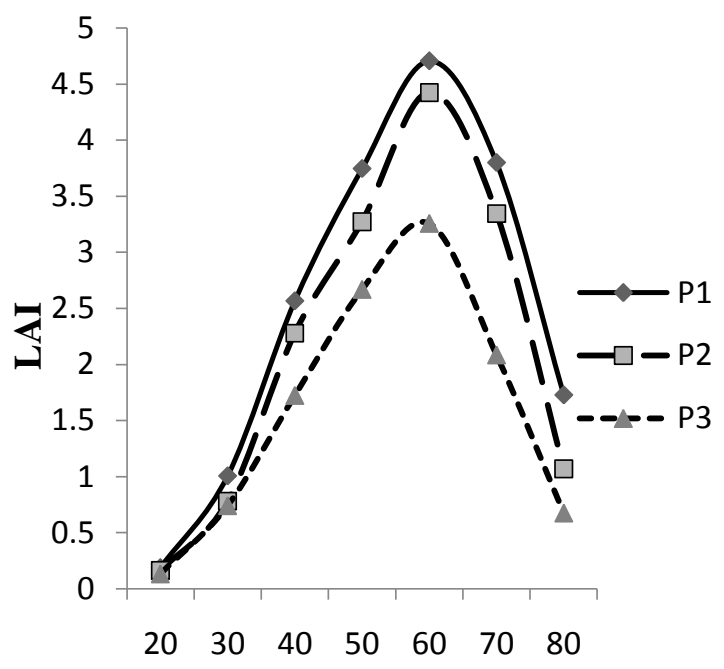

Days after sowing

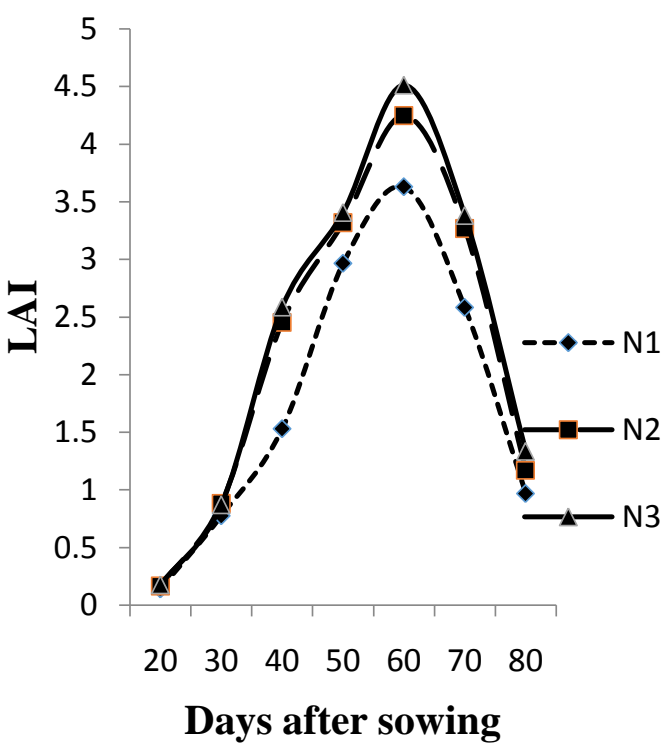

Figure 1. Effect of different planting densities \& Nitrogen levels on leaf area index during the growth season 

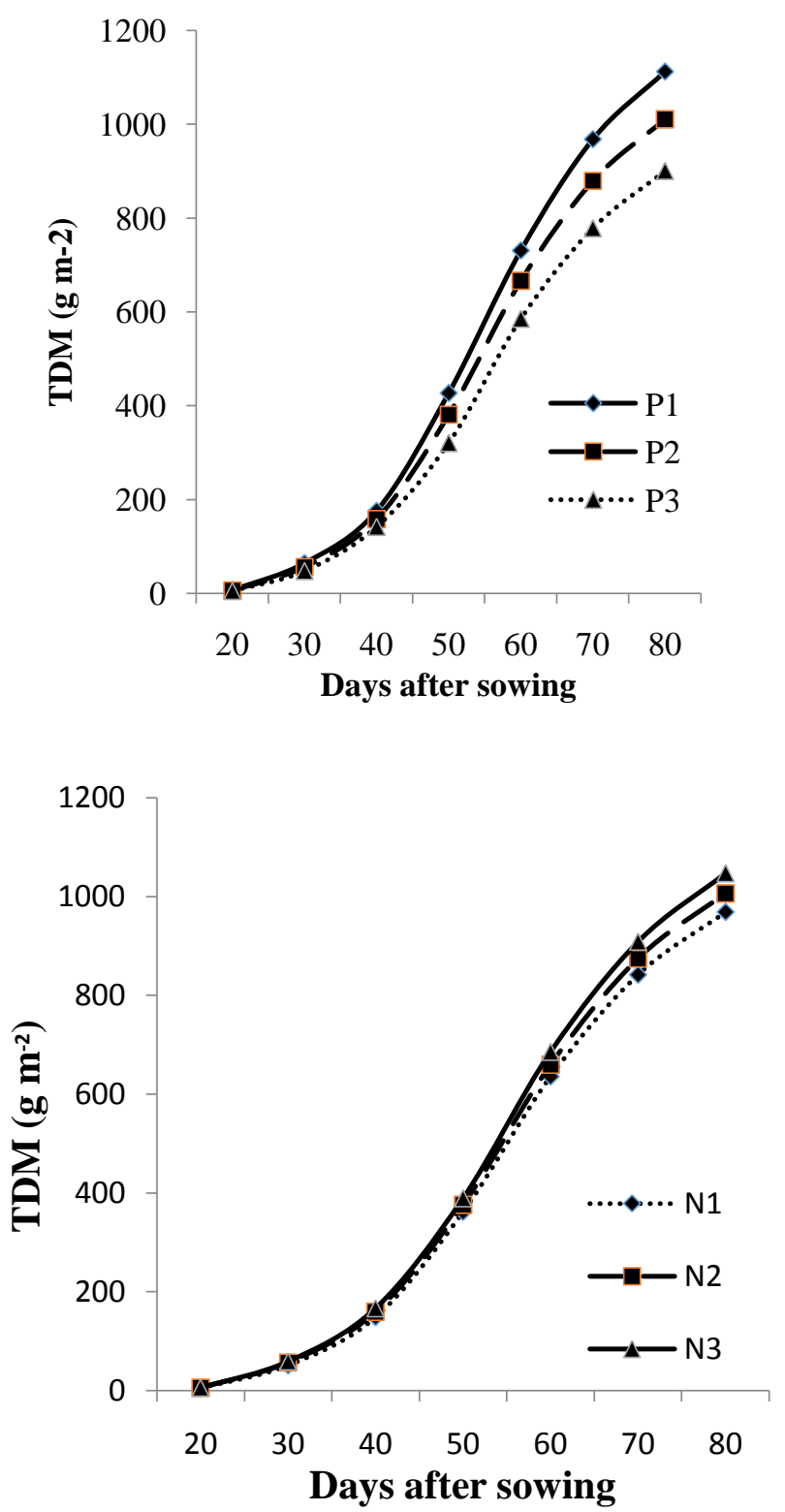

Figure 2. Effect of different planting density \& nitrogen levels on total dry matter during the growth season 

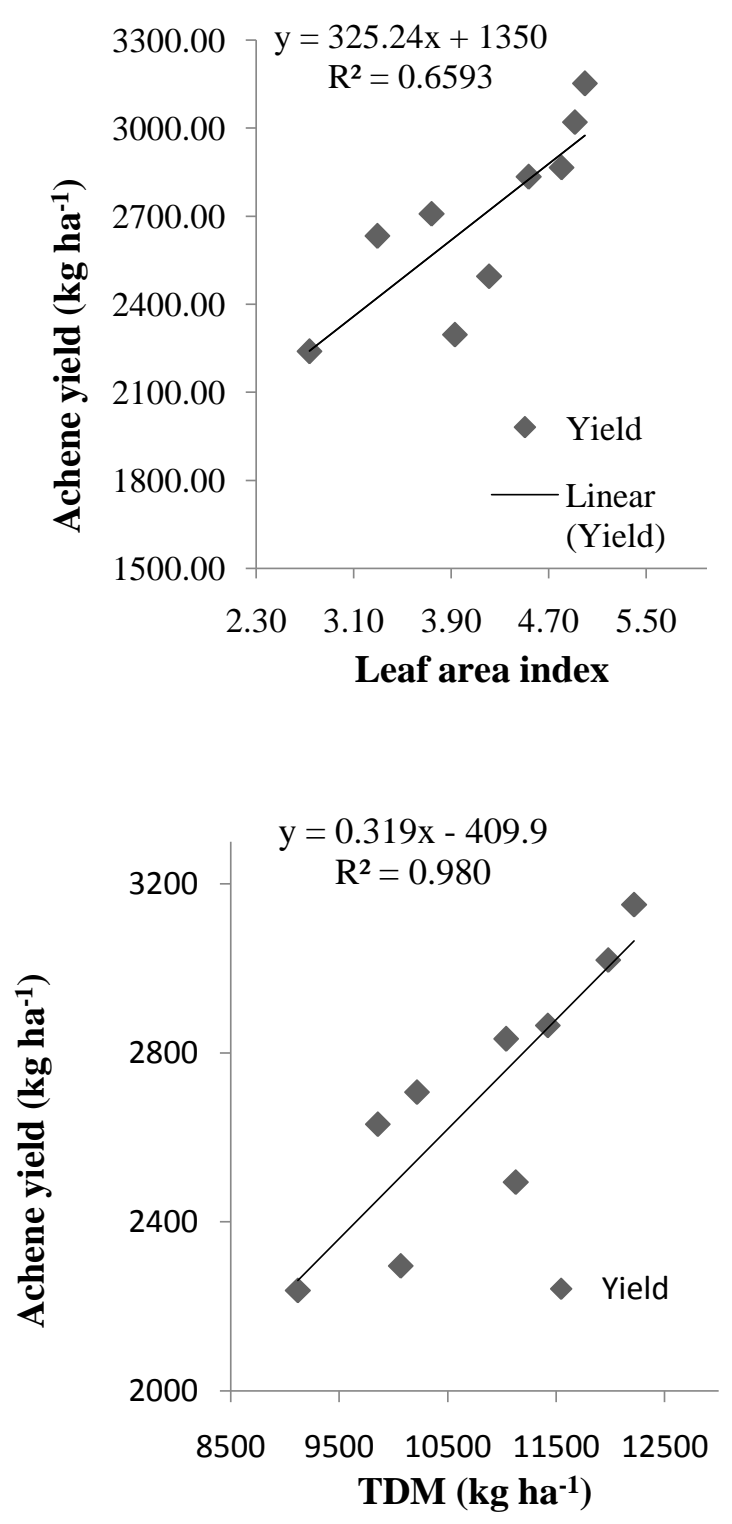

Figure 3. Relationship of achene yield $\left(\mathrm{kg} \mathrm{ha}^{-1}\right)$ with LAI and TDM $\left(\mathrm{kg} \mathrm{ha}^{-1}\right)$ 


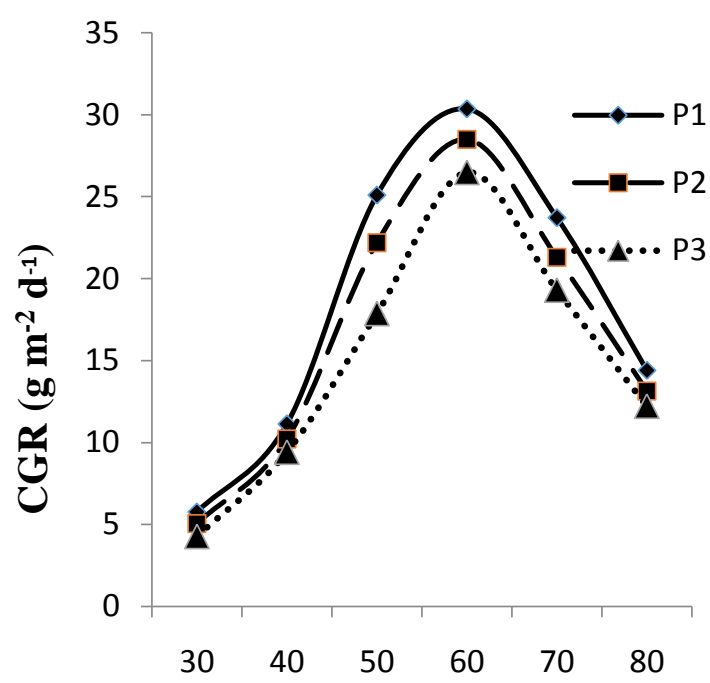

Days after sowing

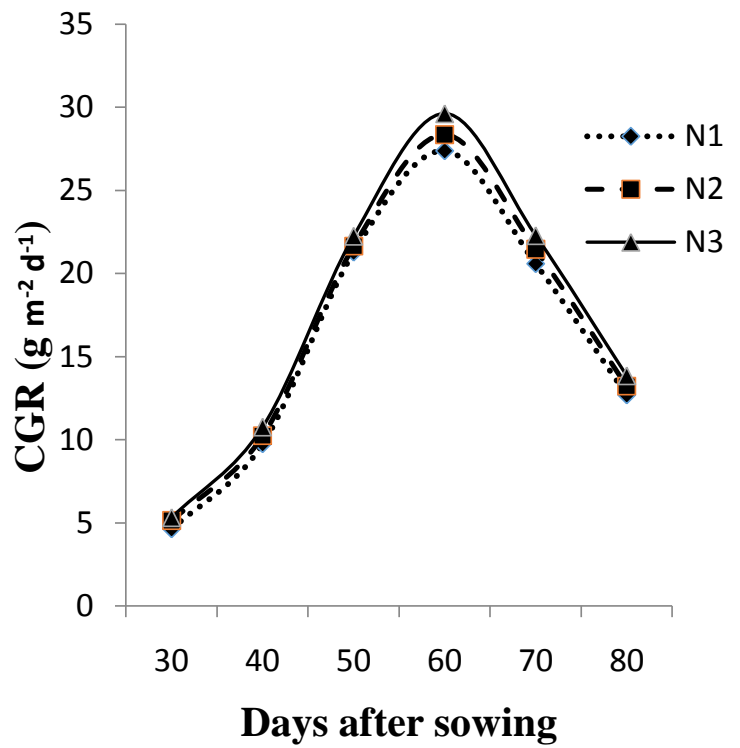

Figure 4. Effect of different plant population \& nitrogen levels on crop growth rateduring the growth season 